\title{
The larva of Tracbypholis variegata Sharp, 1885 (Coleoptera: Zopheridae: Colydiinae) with the key to larval Synchitini from Russia
}

\section{Описание кичинки Trachypholis variegata Sharp, 1885 (Coleoptera: Zopheridae: Colydiinae), и таблиџа для определения мичинок трибы Synchitini фауны России}

\author{
Artyom A. Zaitsev \\ А.А. Зайџев \\ Moscow State Pedagogical University (MSPU), Institute of Biology and Chemistry, Department of Zoology and Ecology, Kibaltchicha str. \\ 6-3, 129164 Moscow, Russia. E-mail: ztema@mail.ru \\ KEY WORDS: Coleoptera, Zopheridae, Synchitini, larvae, morphology, South Kuril Islands. \\ КЛЮчЕВЫЕ СЛОВА: Coleoptera, Zopheridae, Synchitini, личинки, морфология, Южные Курилы.
}

\begin{abstract}
The late-instar larva of Trachypholis variegata Sharp, 1885 from Kunashir island (Russia, South Kurils) is described and compared with other Synchitini larvae. A key to genera of Synchitini based on the known larvae is provided.
\end{abstract}

РЕЗЮМЕ. Описывается личинка последнего возраста Trachypholis variegata Sharp, 1885 с острова Кунашир (Россия, Южные Курилы). Проводится её сравнение с другими личинками трибы Synchitini. Составлен определительный ключ по личинкам Synchitini, известных с территории России.

\section{Introduction}

Zopheridae is a large and diverse family of Coleoptera, with appr. 190 genera and 1700 species distributed worldwide [Ślipiński, Lawrence, 2010]. It composed of two subfamilies, Zopherinae and Colydiinae, the latter with 6 tribes recorded for the Palaearctic region: Colydiini, Gempylodini, Nematidiini, Orthocerini, Rhopalocerini and Synchitini. Synchitini is the largest tribe of Colydiinae and presented by 31 genera and appr. 200 species in the Palaearctic, with 12 genera and 21 species known from Russia [Ślipiński, Schuch, 2008]. Larvae of Synchitini occurring in Russia are studied rather well and described for Bitoma crenata Fabricius, 1775 [Mamaev, 1975; Nikitsky, Belov, 1980; Perris, 1853], Colobicus hirtus Rossi, 1790 [Hayashi, 1972; Nikitsky, Belov, 1980; Perris, 1877], Endophloeus exculptus Germar, 1847 [Mamaev, 1975], Langelandia anophthalma Aubè, 1842 [Dajoz, 1968], Lasconotus jelskii Wankowicz, 1867 [Mamaev, 1975; Saalas, 1923], Lastrema verrucicollis Reitter, 1880 [Nikitsky, Belov, 1980], Niphopelta imperialis Reitter,
1882 [Nikitsky, Belov, 1980] and genus Synchita: S. humeralis Fabricius, 1792, S. separanda Reitter, 1882, S. mediolanensis A. Villa et J. B. Villa 1833, S. (Cicones) undata Guèrin-Mèneville, 1844 [Nikitsky, Belov, 1980]. Thus, larvae are not described for genera Nosodomodes Reitter, 1922, Corticus Germar, 1824, Xylolaemus L. Redtenbacher, 1857 and, until present paper, Trachypholis Erichson, 1845. The genus Trachypholis includes 13 species in Palaearctic [Ślipiński, Schuch, 2008] with only one species Trachypholis variegata Sharp, 1885 known from Russia (Far East: Sakhalin and Kuril Islands). In this paper, the detailed description of the lateinstar larva of T. variegata is given with comparison of other known larvae of Synchitini from Russia.

\section{Materials and methods}

Larvae of T. variegata were collected together with adults under bark of Abies sachalinensis (F. Schmidt) Masters 1879, inhabited by Polygraphus spp. and identified by association with adults (Figs 1-4).

SEM photographs were taken with a Jeol JSM-6380 scanning electon microscope. After cleaning, the specimens were dried using a Hitachi HCP-1 critical point dryer and coated with gold using a Hitachi IB-3 sputter coater. Habitus and digital photographs were taken with a Canon 40D camera with a MP-E $65 \mathrm{~mm}$ macro lens attached to a Leica MZ6 support. Photos were processed using Zerene Stacker software. Drawings were made in Corel Draw 12. The specimens preserved in $75 \%$ ethanol or on slides are deposited in Moscow State Pedagogical University, Moscow, Russia (MSPU).

MATERIAL EXAMINED. 23 late-instar larvae: South Kuril

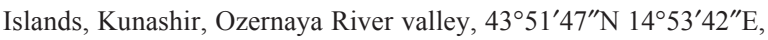
23.VIII.2009, A. Zaitsev (MSPU). Additional larval material stud- 
ied: Bitoma crenata, Colobicus hirtus, Endophloeus exsculptus, Lastrema verrucicollis, Synchita humeralis (Colydiinae: Synchitini), Pycnomerus sulcicollis Germar, 1824 (Zopherinae: Pycnomerini).

\section{Results}

DESCRIPTION. Late-instar larva. Maximum body length about $11 \mathrm{~mm}$; head length $0.70 \mathrm{~mm}$; urogomphi length $0.4 \mathrm{~mm}$; maximum width of thorax $1 \mathrm{~mm}$; maximum width of abdomen $1.30 \mathrm{~mm}$. Body elongated, cylindrical; widest across abdominal segment $\mathrm{V}$, slightly tapering anterad and posterad; urogomphi well-developed (Fig. 4). Body white with terga slightly yellowish; head dark yellow, abdominal segment IX and urogomphi brown, mandibles light brown. Dorsal vestiture consists of two rows of simple setae and two pairs of long setae, each located laterally; ventral surfaces with microgranulae, and simple
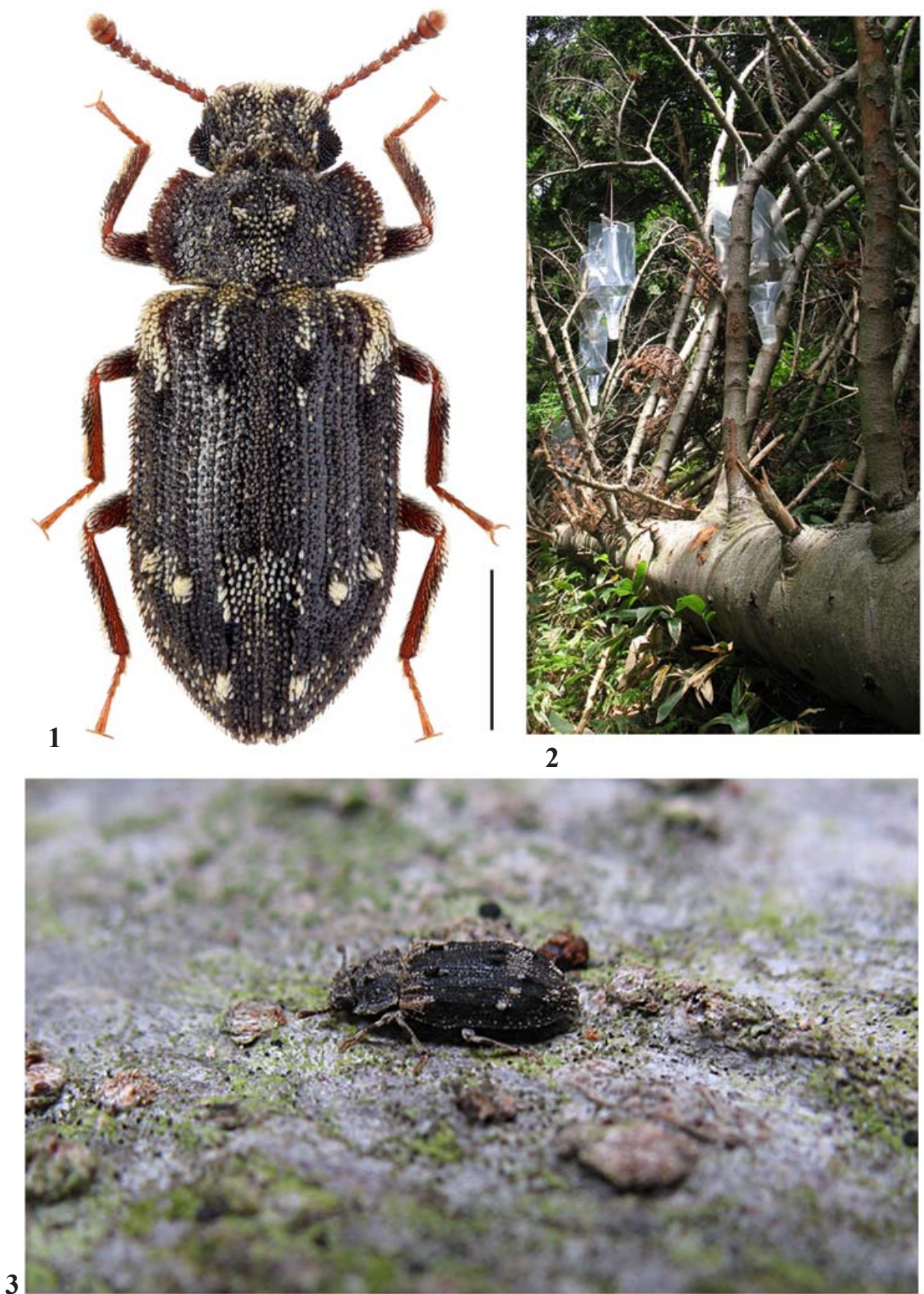

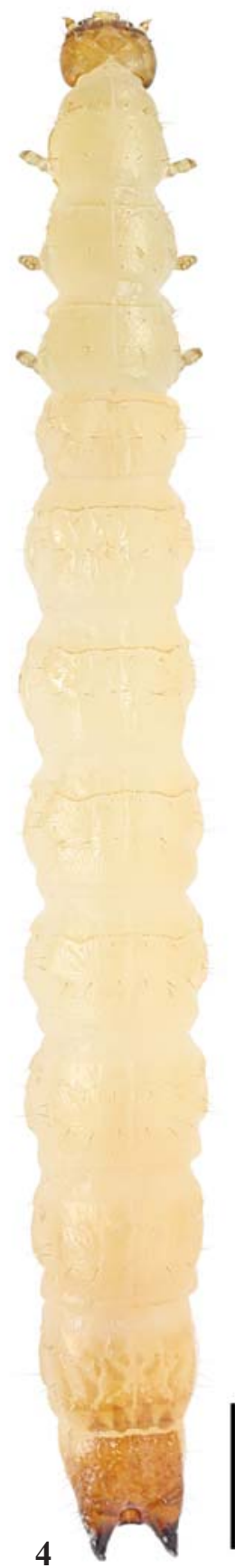

4

Figs 1-4. Trachypholis variegata: 1 - adult, dorsal view; 2 - habitat; 3 - adult on the bark of Abies sachalinensis; 4 - late-instar larva, dorsal view. Scale bars $-1 \mathrm{~mm}$.

Рис. 1-4. Trachypholis variegata: 1 - имаго, сверху; 2 - местообитаниt; 3 - имаго на коре пихты сахалинской; 4 - личинка последнего возраста, сверху. Масштабная линейка - 1 мм. 
setae; legs covered with long, pointed setae (Figs 5-7).

Head (Figs 8-9, 11) prognathous, transverse, slightly flattened; dorsally about 1.16 as long as wide and 0.6 as wide as prothorax; dorsally with 5 long and 8 short setae. Epicranial stem very short, frontal arms well developed, lyriform (Fig. 8). Stemmata (Fig. 14) 5 on each side, composing 2 rows, with 3 stemmata on anterior and 2 on posterior row. Hypostomal rods present (Fig. 9). Fronto-clypeal suture absent (Fig. 8). Clypeus with 4 long and 2 lesser setae. Labrum transverse, about 0.6 as long as wide, sclerotized, free, with 6 long setae dorsally, its anterior margin rounded and bears 10 short setae (Fig. 10). Antenna 3-segmented, with well-devel-
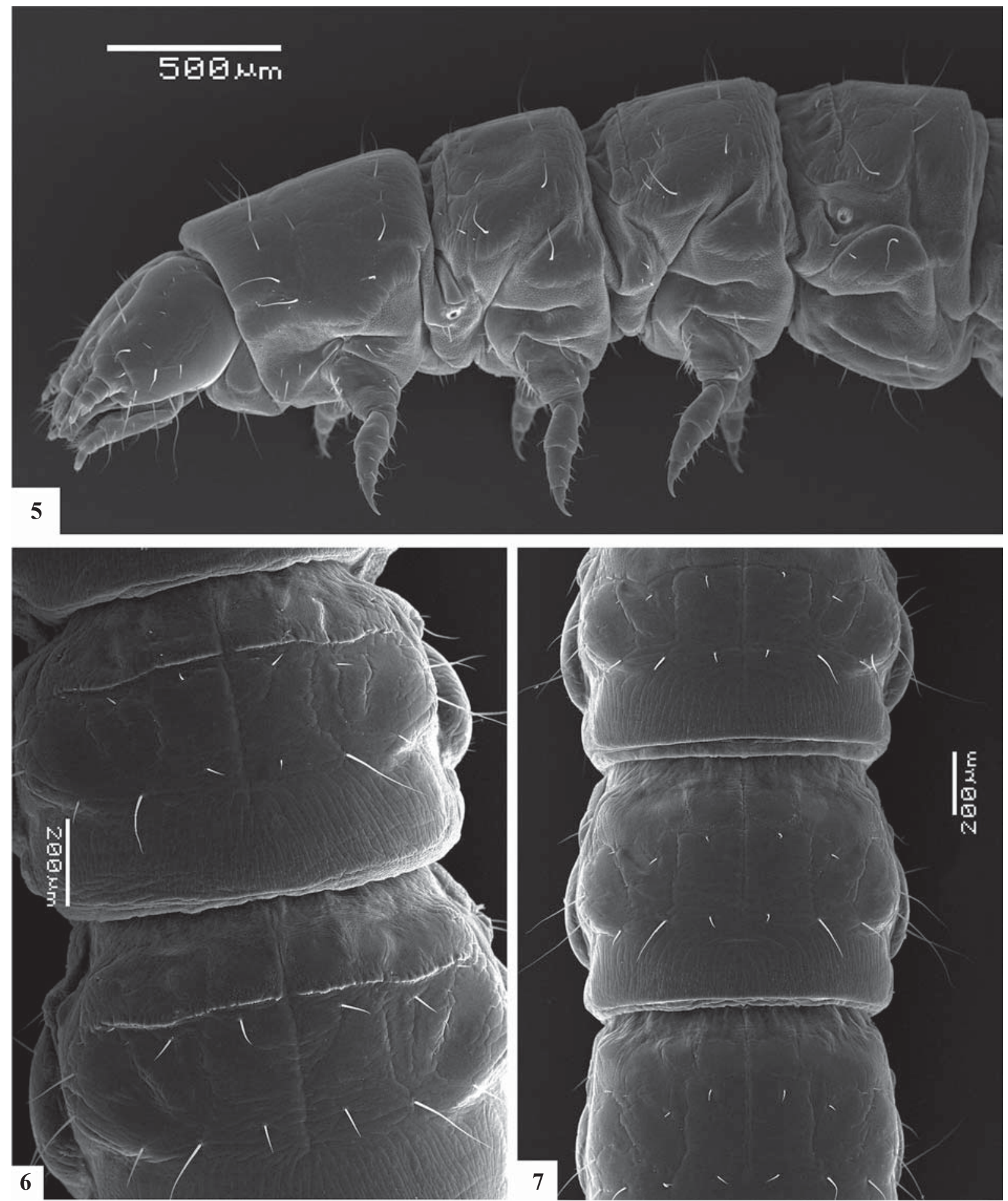

Figs 5-7. Trachypholis variegata late-instar larva: 5 - head, thorax and abdominal segment I, laterally; 6 - thoracic segments II-III, dorsally; 7 - abdominal segments V-VII, dorsally.

Рис. 5-7. Trachypholis variegata, личинка последнего возраста: 5 - голова, грудь и I сегмент брюшка, сбоку; 6 - II-III грудные сегменты, сверху; 7 - V-VII сегменты брюшка, сверху. 
oped conical sensorium on antennomere 2 (Figs 12-13). Antennomere 1 with microgranulae on apical part and without setae; antennomere 2 is slightly smaller than first and bears 3 long and 1 short setae, sensorium is 1.8 times shorter than antennomere 2; antennomere 3 is 1.3 as long as first and
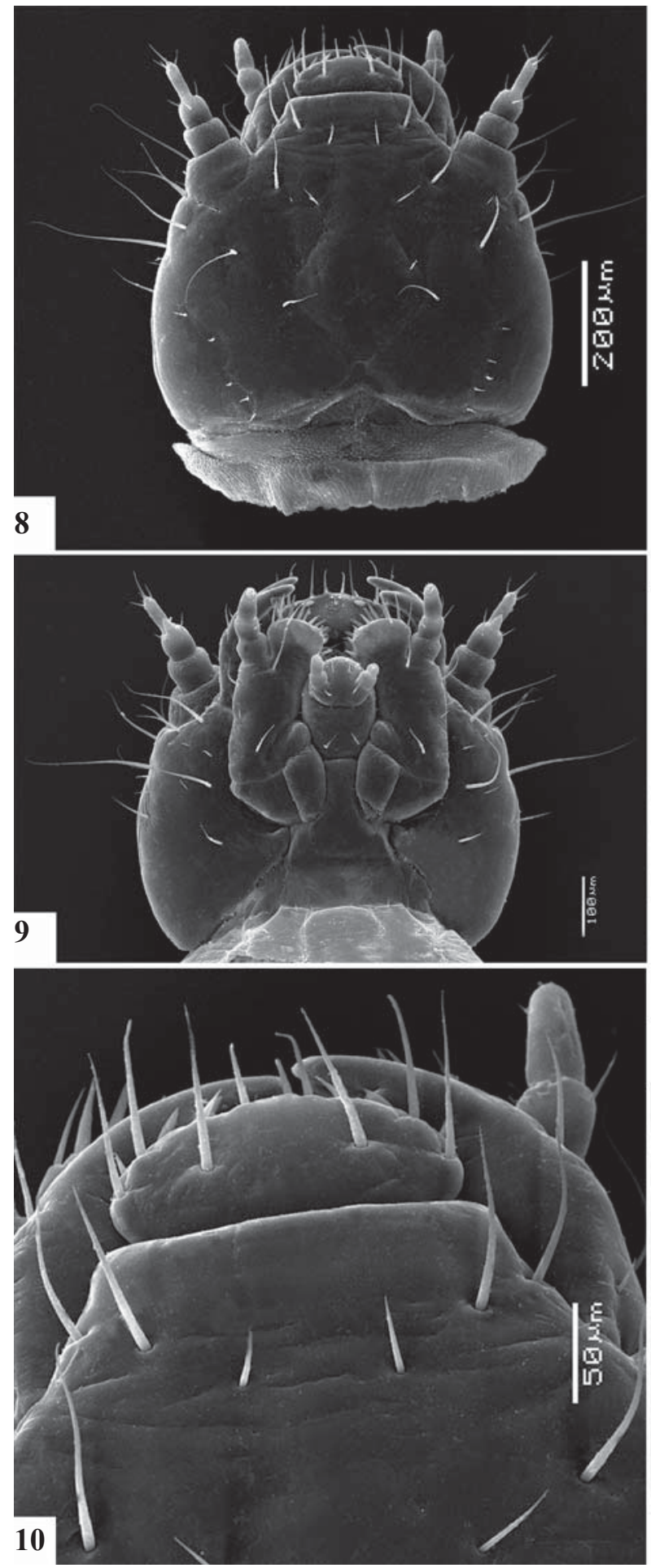

bears 3 long and 3 short setae. Mandibles transverse, symmetrical, bidentate; prostheca absent; mola well developed, its surface with asperities forming discrete, transverse rows (Figs 15-16). Maxillolabial complex retracted (Fig. 17). Maxilla with cardo well-developed, subtriangular; stipes elon-
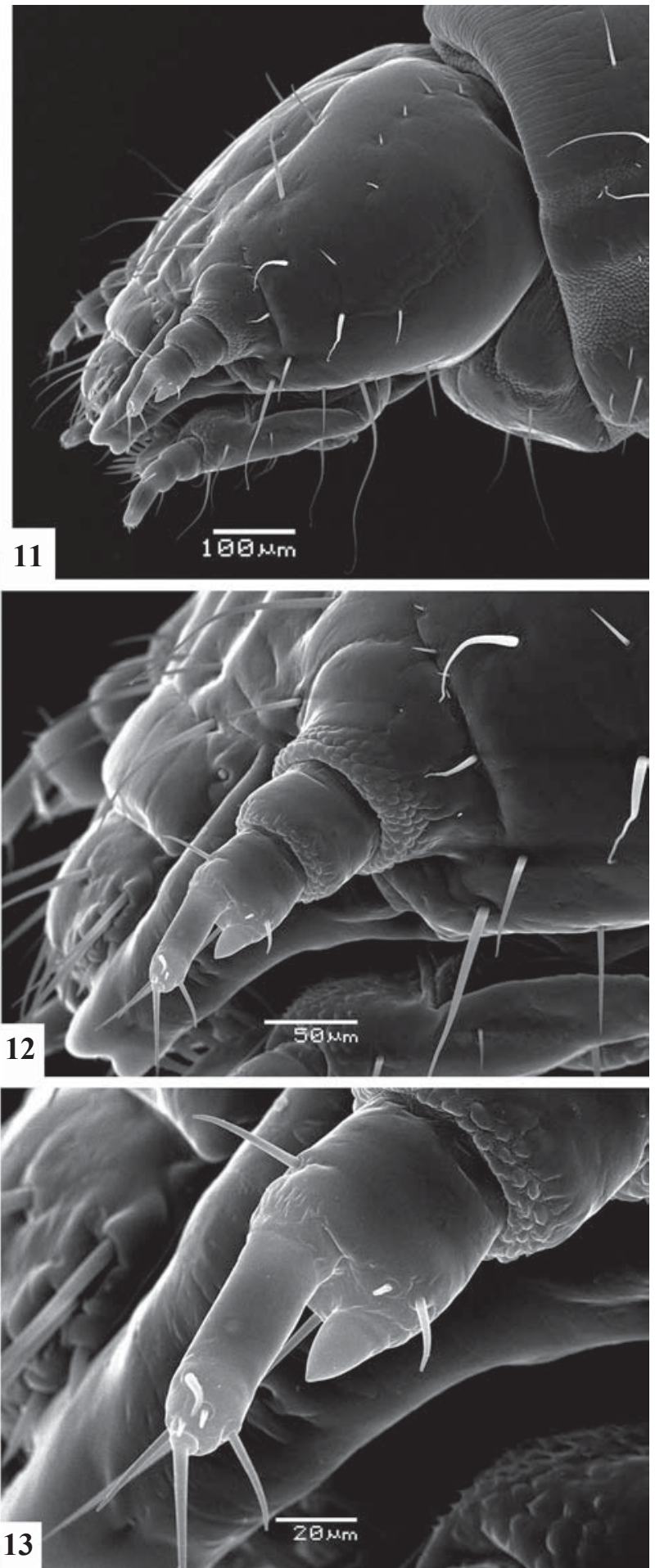

Figs 8-13. Trachypholis variegata late-instar larva: 8-9, 11 - head; 10 - labrum; 12 - antenna; 13 - antennomere 2-3; 8, $10-$ dorsally; 9 - ventrally; $11-13$ - laterally.

Рис. 8-13. Trachypholis variegata, личинка последнего возраста: 8-9, 11 - голова; 10 - верхняя губа; 12 - антенна; $13-2-3$ членики антенн; 8, 10 - сверху; 9 - снизу; 11-13 - сбоку. 
gate, with 3 setae near outer edge and 1 seta near the basis; mala well-developed, slightly broad and rounded apically, with 10 rather long apical setae; maxillary palpi 3-segmented; palpomeres 1 and 2 transverse, equal in length, palpomere 1 without setae, palpomere 2 with several short setae, palpo- mere 3 about 1.25 as long as palpomere 1, slightly tapered, blunt at apex, and bearing a group of short apical sensory processes and large digitiform sensorium (Fig. 18). Epipharynx with numerous short and stout setae (Fig. 17). Labium with mostly membranous mentum with 2 long setae; premen-
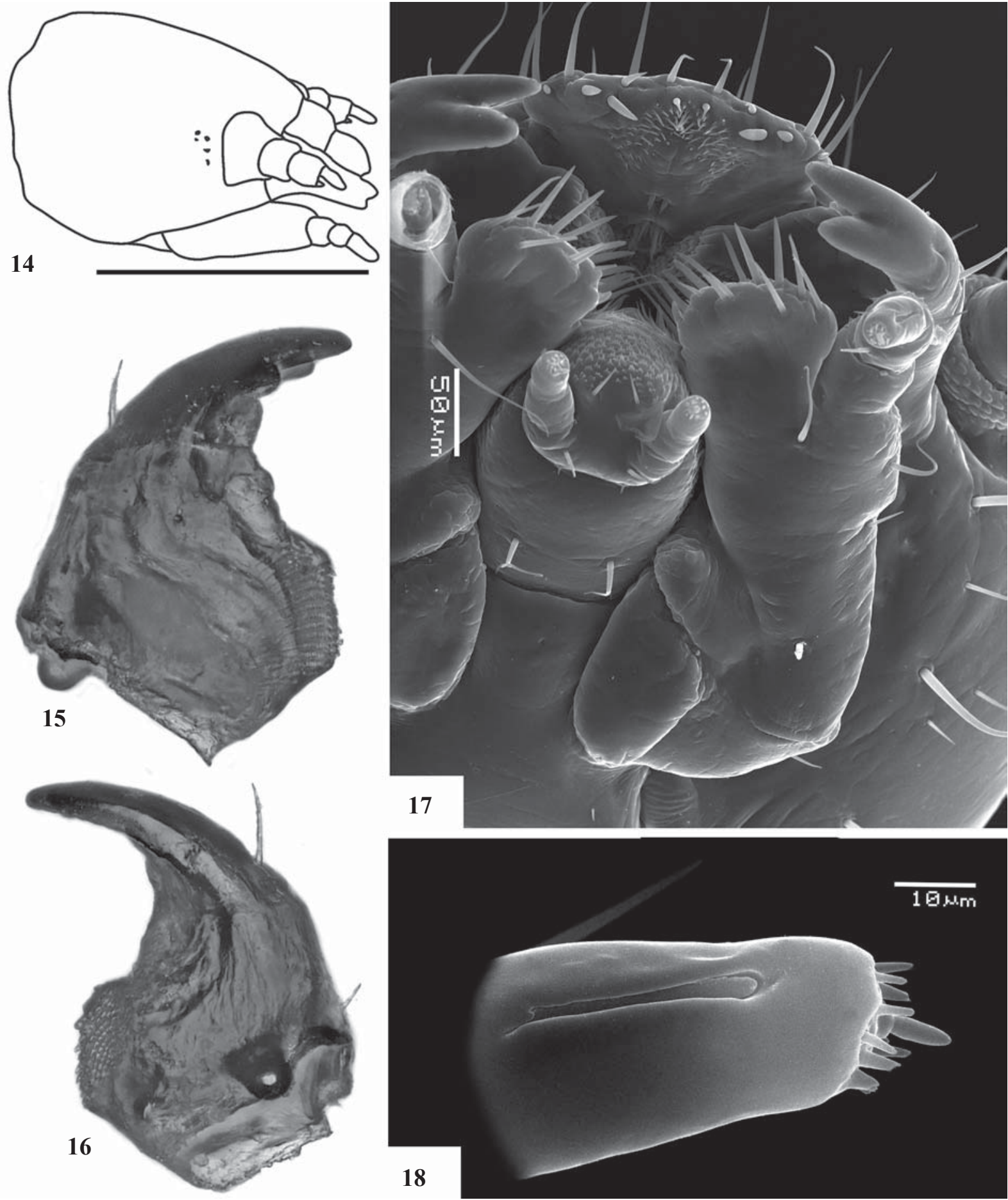

Figs 14-18. Trachypholis variegata late-instar larva: 14 - head schematically, showing stemmata, scale bar $-0.5 \mathrm{~mm} ; 15-$ left mandible, dorsally; 16 - right mandible, ventrally; 17 - epipharynx and maxillo-labial complex, ventrally; 18 - maxillary terminal palpomere with digitiform sensorium.

Рис. 14-18. Trachypholis variegata, личинка последнего возраста: 14 - головная капсула (схематично), показано расположение глазков, масштабная линейка - 0,5 мм; 15 - левая мандибула, сверху; 16 - правая мандибула, снизу; 17 — эпифаринкс и лабиомаксиллярный комплекс, снизу; 18 - последний членик максилл с пальцевидной сенсиллой. 
tum with 4 smaller setae near the base of labial palpomeres; ligula present, with numerous small asperities and 2 setae; labial palpomeres 2-segmented, widely separated; palpomere I without setae, slightly shorter than terminal palpomere; terminal palpomere subcylindrical, blunt at apex, with a group of apical sensilla (Figs 9, 17).

Thorax 0.2 as long as total body length, widest across meso- and metathorax. Thoracic and abdominal terga with median ecdycial line. Each thoracic segment with 2 rows of dorsal setae and several longer lateral setae, meso- and metatergum with anterior transverse row of small heavy sclerotized asperities (Figs 4, 6). Thoracic spiracle annular-biforuous (Fig. 21). Legs 5 segmented. Coxae covered with numerous moderately long, pointed setae; trochanter with 3 setae ventrally; femur subcylindrical, about 1.6 as long as wide, with several rather long setae; tibiotarsus 1.4 as long as femur, tapered

Fig. 23. Trachypholis variegata late-instar larva, VIII-IX abdominal segments, dorsally. Scale bar $-0.5 \mathrm{~mm}$.

Рис. 23. Trachypholis variegata, личинка последнего возраста, VIII-IX сегменты брюшка, сверху. Масштабная линейка - 0,5 мм.
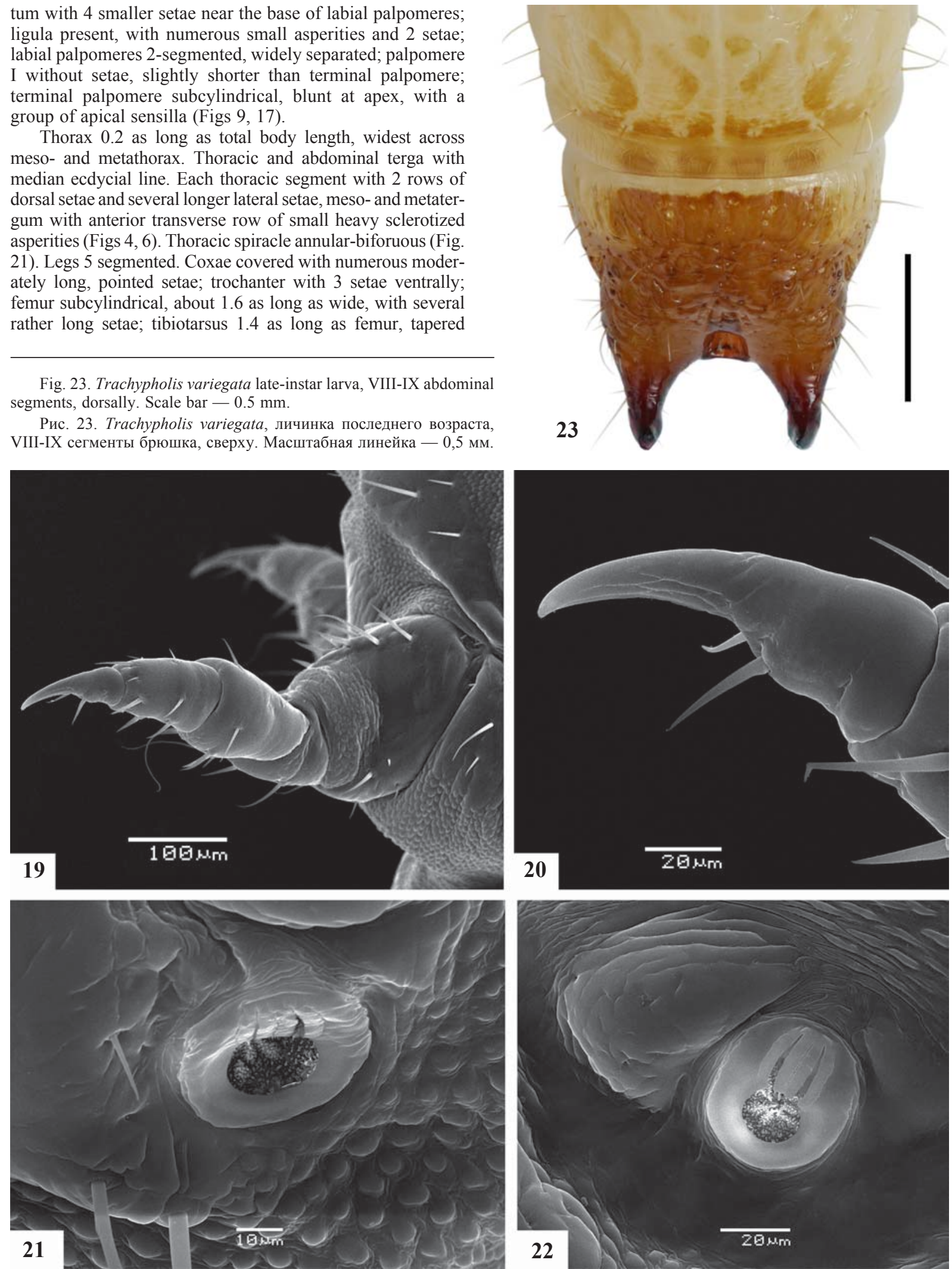

Figs 19-22. Trachypholis variegata late-instar larva: 19 - prothoracic leg, laterally; 20 — tibiotarsus and claw, laterally; 21 - thoracic spiracle; 22 - abdominal spiracle.

Рис. 19-22. Trachypholis variegata, личинка последнего возраста: 19 — нога 1-ой пары, сбоку; 20 — голенелапка и коготок, сбоку; 21 - грудное дыхальце; 22 - брюшное дыхальце. 
apically, bearing 8 small setae, with a single long and sharp claw with 2 setae ventrally (Figs 19-20).

Abdomen widest across segment $\mathrm{V}$, slightly tapered anteriorly; abdominal segments I-VI with anterior transverse row of small heavy sclerotized asperities (Figs 2, 5). Chaetotaxy of abdominal segments I-VIII similar to those on thorax. Segment VIII about 1.2 wider than segment IX, with characteristic pattern of sclerotised spots (Fig. 23). Tergum IX in anterior part with transverse row of 4 equal spots, and bears two cavities (Figs 23-24). The rest of it heavily sclerotised with several long and numerous short setae. Urogomphi welldeveloped, simple and upturned; covered in numerous long
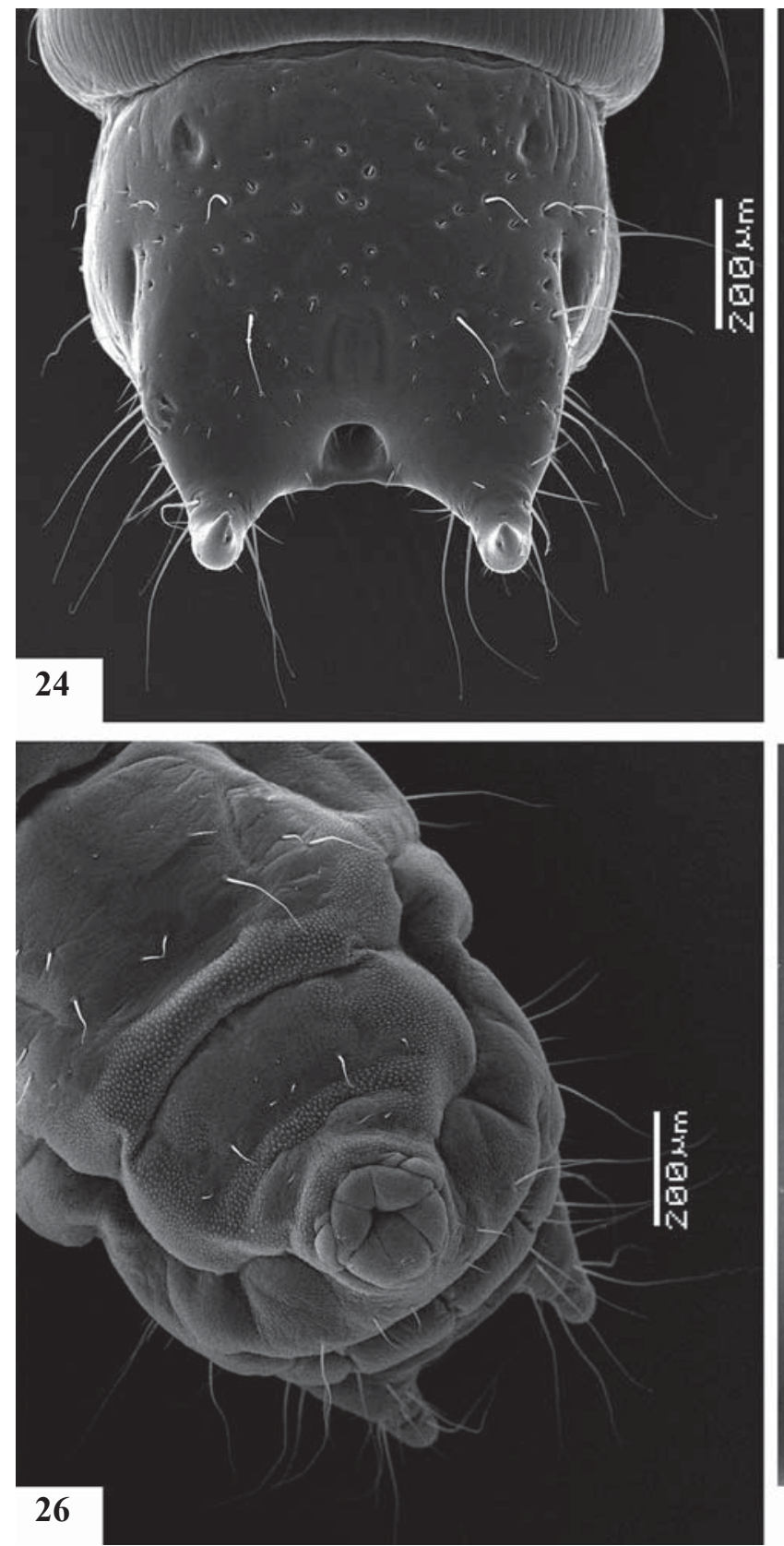

and shorter setae (Figs 23-25); urogomphal pit distinct, trapezoidal, slightly tapered anteriorly and bears 4 setae (Fig. 27). Sternum IX with microgranulae; segment $X$ short, directed posteroventrally (Fig. 26). Spiracles annular-biforous (Fig. 22).

DIAGNOSIS. The late-instar larva of T. variegata can be easily distinguished from larvae of other Synchitini by the characteristic pattern of spots on VIII and IX abdominal segments, and by the rows of heavy sclerotised asperities on meso-and metathorax as well as on I-VI abdominal segments. Larvae of B. crenata, C.hirtus and L. verrucicollis also have such rows of asperities, but they are not so distinct
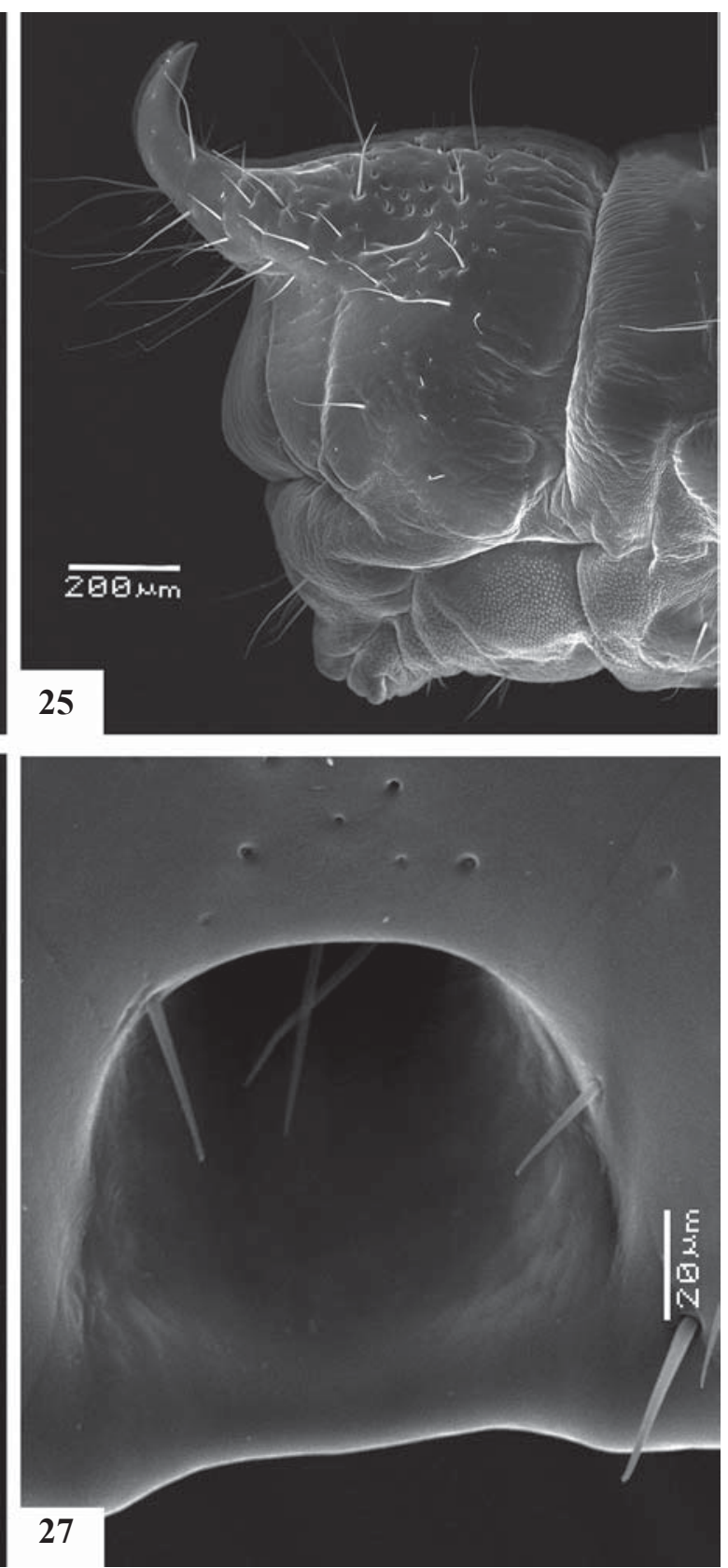

Figs 24-27. Trachypholis variegata late-instar larva, IX abdominal segment: 24 — dorsally; 25 — laterally; 26 — ventrally; 27 urogomphal pit, dorsally.

Рис. 24-27. Trachypholis variegata, личинка последнего возраста, IX сегмент брюшка: 24 - сверху; 25 - сбоку; 26 - снизу; 27 - кармановидное впячивание между основаниями урогомф, сверху. 


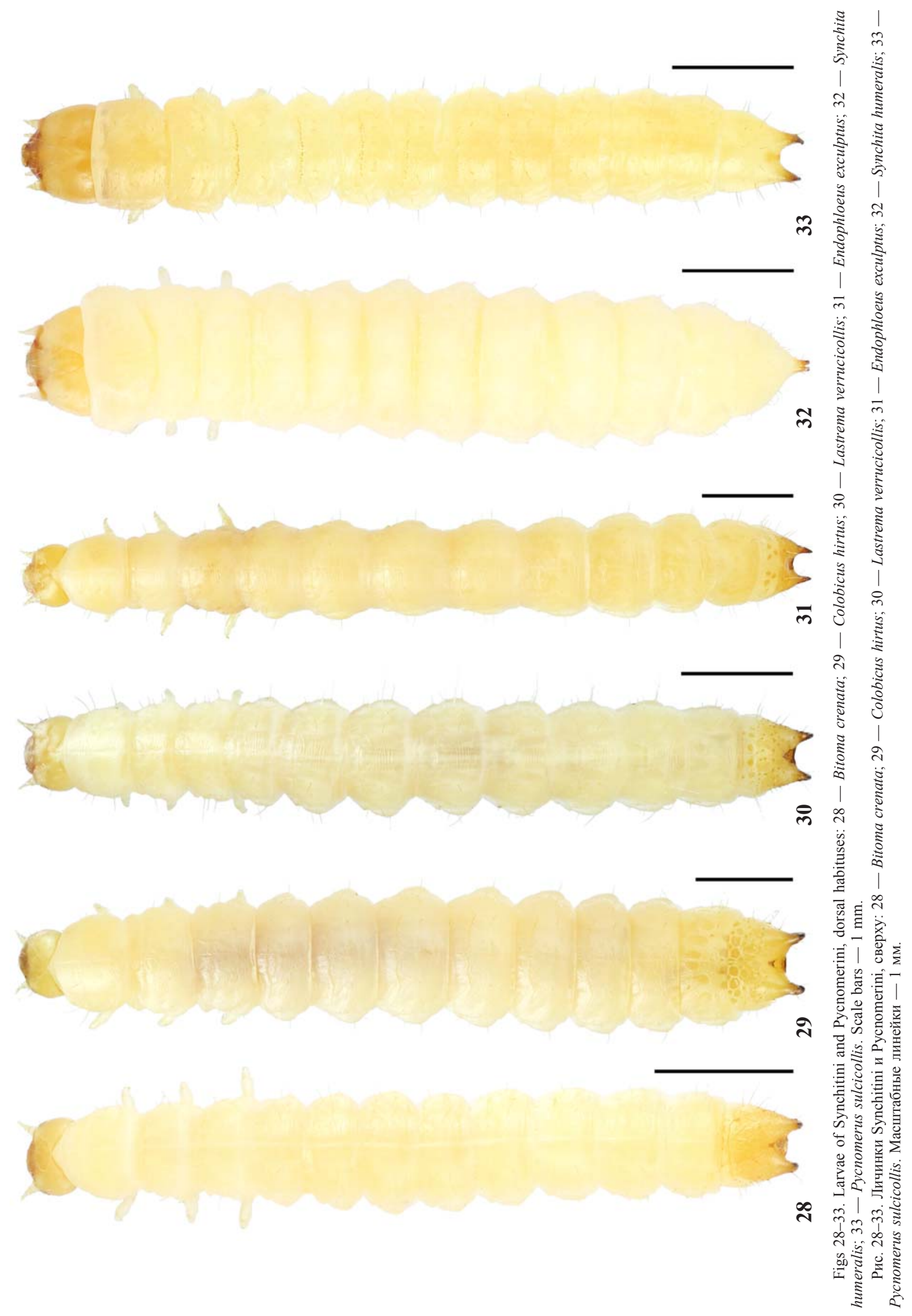



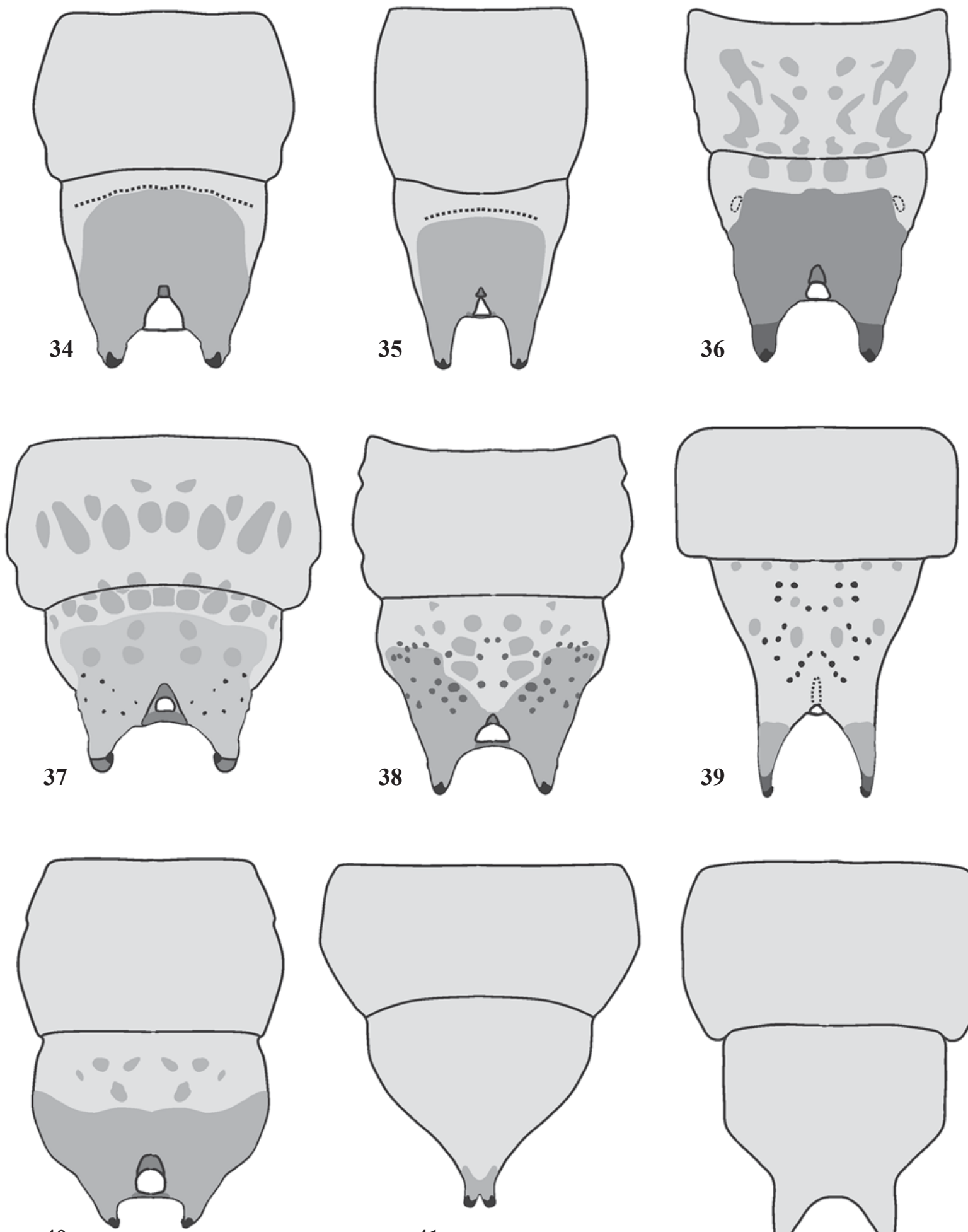

41

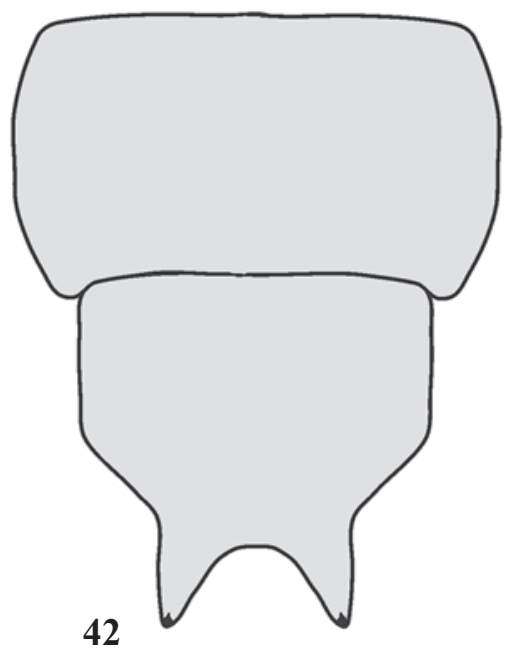

Figs 34-42. VIII-IX abdominal segments of Synchitini larvae, dorsally (schematically, setae omitted): 34 - Bitoma crenata; 35 Lasconotus jelskii [modified from Saalas, 1923]; 36 - Trachypholis variegata; 37 - Colobicus hirtus; 38 - Lastrema verrucicollis; 39 Niphopelta orientalis [modified from Nikitsky, Belov, 1980]; 40 — Endophloeus exsculptus; 41 — Synchita humeralis; 42 — Langelandia anophthalma [modified from Dajoz, 1968].

Рис. 34 42. VIII-IX сегменты брюшка личинок Synchitini, сверху (схематично, хеты не показаны): 34 - Bitoma crenata; 35 Lasconotus jelskii [по Saalas, 1923]; 36 - Trachypholis variegata; 37 - Colobicus hirtus; 38 - Lastrema verrucicollis; 39 - Niphopelta orientalis [по Nikitsky, Belov, 1980]; 40 — Endophloeus exsculptus; 41 — Synchita humeralis; 42 — Langelandia anophthalma [по Dajoz, 1968]. 
and their larvae can be easily differed from Trachypholis by the sclerotisation of VIII and IX abdominal segments (Figs 28-30). Heavy sclerotised rows of asperities similar to T. variegata can be found in the larva of Pycnomerus sulcicollis (Zopherinae: Pycnomerini) but again they are easily distinguished by the structure of VIII-IX abdominal segments, lack of stemmata and urogomphal pit as well as other features (Fig. 33).

With larva of $T$. variegata described it is possible to modify the key to the known late-instar larvae of Synchitini occurring in Russia, which was provided by Nikitsky [Nikitsky, Belov, 1980]. Larvae of genera Langelandia, Lasconotus and Niphopelta were not available in the present study so their features are based on literature [Dajoz, 1968; Nikitsky, Belov, 1980; Saalas, 1923].

KEY TO THE GENERA OF KNOWN LATE-INSTAR LARVAE OF SyNCHITINI OCCURRING IN RUSSIA

1. Transverse row of sclerotised asperities well developed on thoracic segments II-III and on abdominal segments IVI. Urogomphal pit always present (Figs 4, 28-30) .. 2

- Transverse rows of sclerotised asperities absent, urogomphal pit, if present, ovate (Figs 31-32) ................... 7

2. Sclerotised band on abdominal tergum IX (further ATIX) present (Figs 28, 34-35), urogomphal pit triangular, sometimes arcuated

- Sclerotised band on ATIX absent, urogomphal pit trapezoidal.....

3. Frontal arms at basis form an obtuse angle. Abdominal segment VIII about 0.8 as long as abdominal segment IX. Urogomphal pit arcuated (Figs 28, 34)

Bitoma (B. crenata)

- Frontal arms at basis form an acute angle. Abdominal segment VIII almost as long as abdominal segment IX. Urogomphal pit triangular, not arcuated (Fig. 35) ........ Lasconotus (L. jelskii)

4. ATVIII with characteristic pattern of sclerotised spots (Figs 4, 37) .....

— ATVIII without sclerotised spots (Figs 30, 38-39) ... 6

5. Pattern of sclerotised spots on ATVIII as on Fig. 36. ATIX heavy sclerotised, its anterior part with transverse row of 4 spots and bears two cavities (Figs 4, 23, 24, 36)........ Trachypholis (T. variegata)

- Pattern of sclerotised spots on ATVIII as on Fig.37. ATIX less sclerotised, with transverse row of 11 spots in anterior part, cavities absent; also there are 6 spots in the middle part. Bases of urogomphi with several small heavy sclerotised asperities (Figs 29, 37) ........ Colobicus (C. hirtus)

6. Pattern of sclerotised spots on ATIX as on Fig. 38, most part of ATIX with numerous rather large tubercles. Urogomphi about 0.3 as long as abdominal segment IX (Figs 30, 38) Lastrema (L. verrucicollis)
- Pattern of sclerotised spots on ATIX as on fig. 39, the number of tubercles on ATIX distinctly less than in Lastrema. Urogomphi about 0.5 as long as abdominal segment IX. Urogomphal pit distinctly smaller than in Lastrema (Fig. 39) ...

Niphopelta ( $N$. imperialis)

7. Urogomphal pit absent

- Urogomphat pit present, well-deve half of ATIX with 8 sclerotised spots. Apices of urogomphi distinctly inturned (Figs 31, 40)

Endophloeus (E. exsculptus)

8. Thoracic segment I distinctly wider than thoracic segments II-III (Fig. 32), body surfaces lightly sclerotised, urogomphi short, closed at basis (Fig. 41). Stemmata present Synchita (S. humeralis)

- Thoracic segment I insignificantly wider than thoracic segments II-III, urogomphi not closed at basis (Fig. 42). Stemmata absent Langelandia (L. anophthalma)

ACKNOWLEDGEMENTS. I thank K.V. Makarov (MSPU) for providing the adult photo of $T$. variegata, and A.A. Polilov (MSU) for the assistance with SEM.

\section{References}

Dajoz R. 1968. Révision des Colydiidae anophthalmes de la faune paléarctique (Col.) IV. Etudes sur les genres Anommatus et Langelandia // Annales de la Société entomologique de France. N.S. T.4. P.975-988

Hayashi N. 1972. On the larvae of some species of Colydiidae, Tetratomidae and Aderidae occurring in Japan (Coleoptera: Cucujoidea) // Kontyu. Vol.40. No.2. P.100-111.

Mamaev B.M. 1975. [Morphological and ecological characteristics of xylophilous cylindrical bark beetles in the fauna of the European part of the U.S.S.R. based on larval indices (Coleopt.: Colydiidae)] // Nauchnye doklady Vysshei Shkoli. Biologicheskiye Nauki. Vol.18. No.12. P.16-22 [In Russian].

Nikitsky N.B., Belov V.V. 1980. [Larvae of cylindrical bark beetles (Coleoptera, Colydiidae) of the European part of the USSR and Caucasus, with comments on taxonomy of the family. 1] // Zoologicheskii Zhurnal. Vol.59. P.1040-1053 [In Russian].

Perris E. 1853. Histoire des insectes du pin maritime. // Annales de la Société entomologique de France. T.3. Fasc.1. P.554-644.

Perris E. 1877. Larves des Coléoptères. (Part)// Annales de la Société linnéenne de Lyon. T.23. (1876) P.1-430. 14 pls.

Saalas U. 1923. Die Fichtenkäfer Finnlands. II. Spezieller Teil 2 und Larvenbestimmungstab // Annales Academiae Scientiarum Fennicae. Ser.A. Bd.22. 746 ss.

Ślipiński S.A., Lawrence, J.F. 2010. 11.9. Zopheridae Solier, 1834, pp. 548-559. // R.G. Beutel, R. Leschen and J. Lawrence (eds.). Handbuch der Zoologie/Handbook of Zoology. Band/Volume IV Arthropoda: Insecta Teilband/Part 38. Coleoptera, Beetles. Morphology and Systematics (Polyphaga partim). W.DeGruyter, Berlin.

Ślipiński S.A., Schuch R. 2008. Zopheridae, pp. 78-87 // I. Löbl \& A. Smetana (ed.): Catalogue of Palaearctic Coleoptera. Vol.5. Stenstrup: Apollo Books 670 pp. 